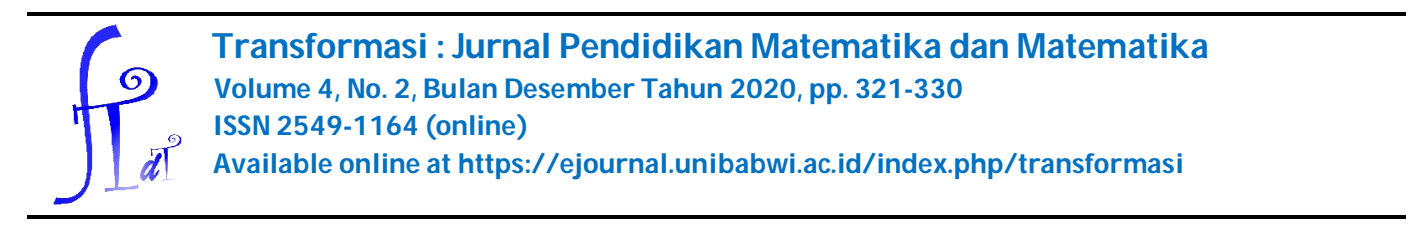

\title{
KEMAMPUAN SPASIAL SISWA \\ MELALUI MODEL PEMBELAJARAN BERBASIS MASALAH BERBANTUAN ALAT PERAGA BERBAHAN PIPET
}

\author{
Andriyani Usman', Amin Fauzi' ${ }^{2}$, Ida Karnasih ${ }^{3}$, Abdul Mujib ${ }^{4}$ \\ 1,3,4 Fakultas Keguruan dan Ilmu Pendidikan, Universitas Muslim Nusantara Al-washliyah \\ 2 Fakultas Matematika dan Ilmu Pengetahuan Alam, Universitas Negeri Medan \\ email korespondensi : andriyaniusman93@gmail.com
}

Diterima : (18-10-2020), Revisi: (18-11-2020), Diterbitkan : (24-12-2020)

\begin{abstract}
ABSTRAK
Tujuan dari penelitian ini untuk mengetahui apakah peningkatan kemampuan spasial matematis siswa menggunakan model pembelajaran berbasis masalah berbantuan Alat peraga lebih tinggi daripada kemampuan spasial siswa yang diajarkan dengan model pembelajaran konvensional. Penelitian ini dilaksanakan pada siswa kelas VIII SMP Swasta Al Ulum Medan yang berjumlah 30 siswa. Jenis penelitian ini adalah quasi eksperimen (eksperimen semu) dengan desain penelitian pre-test-post-tes control group design. Populasi dalam penelitian ini adalah seluruh siswa kelas VIII SMP Swasta Al ulum Medan tahun ajaran 2019/2020 dengan mengambil sampel dua kelas (eksperimen dan kontrol) melalui teknik random sampling yang mana pada masing-masing kelas terdiri dari 15 siswa. Instrumen yang digunakan dalam pengumpulan data terdiri dari tes kemampuan spasial. Data dianalisis dengan menggunakan uji ANAVA dua jalur. Hasil penelitian menunjukan peningkatan kemampuan spasial matematis siswa menggunakan model pembelajaran berbasis masalah berbantuan alat peraga lebih tinggi daripada kemampuan spaisal siswa yang diajarkan dengan model pembelajaran konvensional.
\end{abstract}

Kata Kunci : Alat Peraga, Kemampuan Spasial, Pembelajaran Berbasis Masalah, 


\begin{abstract}
This study aims to determine whether the increase in students' mathematical spatial abilities using a problem-based learning model assisted with teaching aids is higher than the spatial abilities of students taught by conventional learning models. This research was conducted on the eighth-grade students of Al Ulum Medan Private Middle School, totaling 30 students. This type of research is a quasi-experimental (quasi-experimental) research design with a pre-test-post-test control group design. The population in this study were all class VIII students of Al Ulum Medan Private Middle School for the 2019/2020 school year by taking samples of two classes (experiment and control) through random sampling techniques, which in each class consisted of 15 students. The instruments used in Data collection consisted of a spatial ability test. Data were analyzed using a two-way ANOVA test. The results showed: The increase in students 'mathematical spatial abilities using problem-based learning models assisted by teaching aids was higher than the students' spatial abilities taught with conventional learning models.
\end{abstract}

Keywords : Teaching Aids, Spatial Ability, Problem Based Learning

\title{
Pendahuluan
}

Maier (1996 : 69) mengemukakan bahwa kemampuan spasial adalah kualifikasi manusia yang relevan untuk mencapai derajat tinggi dalam kehidupan kita. Maier (1996 : 70) membagi kemampuan spasial atas 5 elemen yaitu (1) Spasial Perseption (persepsi spasial), (2) Visulisation, terdiri dari kemampuan untuk memvisualisasikan konfigurasi dimana ada gerakan atau perpindahan antara bagian konfigurasi, (3) Mental Rotation (Rotasi mental) dimana melibatkan kemampuan secara cepat dan akurat memutar 2D dan 3D, (4) Spatial Relations (hubungan spasial) berarti kemampuan untuk memahami objek konfigurasi spasial atau bagian-bagian dari sebuah objek dan hubungan satu sama lainnya, (5) Spatial Orientation (orientasi spasial) adalah kemampuan untuk menyesuaikan diri secara fisik atau mental dalam ruang. Pada kenyataannya proses pembelajaran matematika, terlihat belum banyak guru yang menciptakan kondisi dan situasi yang melatih siswa untuk mengembangkan kemampuan berpikir spasial, yang mana kemampuan tersebut dapat membantu siswa dalam proses belajar mengajar serta mengenali lingkungan sekitarnya. Misalnya kemampuan hubungan keruangan yang merupakan bagian sangat penting dalam belajar matematika khususnya geometri. Kesulitan siswa dalam pembelajaran geometri sebagai akibat dari rendahnya kemampuan spasial siswa, sementara geometri merupakan salah satu pembelajaran yang penting dalam matematika tentu saja merupakan suatu permasalahan yang harus diatasi. Hasil analisis penelitian dari Mulyadi, Riyadi, \& Subanti (2015)menemukan bahwa presentase kesalahan terbesar siswa dalam kemampuan spasial matematika adalah dalam mentransformasi dan memberikan kesimpulan akhir dalam objek geometri 
siswa masih mengalami kesulitan. Selain itu kurangnya imajinasi untuk memvisualisasikan komponen-komponen bentuk bangun ruang sehingga siswa mengalami kesulitan dalam mengkonstruksi bangun ruang dan menyelesaikan masalah (Siswanto, 2016).

Secara umum kemampuan spasial siswa dalam kegiatan pembelajaran masih kurang diperhatikan. Situasi dan kondisi yang diciptakan dan disediakan guru masih tradisional dan kurang melatih kemampuan spasial siswa. Akibatnya matematika dipandang sebagai salah satu pembelajaran yang abstrak dan sangat membosankan. Guru lebih berperan sebagai subyek pembelajaran dan siswa sebagai objek atau dengan kata lain sistem pembelajaran lebih berpusat kepada guru sehingga menyebabkan banyak siswa mampu menyajikan tingkat hapalan yang baik terhadap materi ajar yang diterimanya, tetapi pada kenyataannya mereka tidak memahaminya. Sebagian besar siswa tidak mampu menghubungkan antara apa yang dipelajari dengan bagaimana pengetahuan tersebut akan dipergunakan atau dimanfaatkan.

Untuk mengetahui kemampuan spasial siswa SMP Swasta Al Ulum Medan peneliti mengadakan observasi awal pada tanggal 15 April 2019 di kelas VIII-4 yang berjumlah 30 siswa. Hasil observasi menunjukan bahwa kemampuan siswa menyelesaikan soal matematika cukup baik, tetapi siswa mengalami kesulitan dalam menyelesaikan soal yang menuntut kemampuan bepikir spasial siswa. Soal tes yang diberikan yaitu soal berpikir spasial pada materi geometri bangun ruang sisi datar. Dalam tes ini yang akan diuji adalah kemampuan siswa untuk melihat sesuatu informasi visual yang tersedia kemudian merekonstruksinya menjadi suatu bangun yang utuh (bangun ruang) atau benda berdimensi. Untuk bisa menjawab permasalahan dan memvisualisasikanya maka dibutuhkan kemampuan untuk berimajinasi dan berpikir secara abstrak. Biasanya soal dalam tes ini terdiri dari bagian-bagian struktur bangun dalam bidang datar, yang kemudian direkonstruksikan menjadi suatu bangun yang utuh berdimensi. Berikut soal yang diberikan kepada siswa untuk mengukur tingkat kemampuan spasial.

Perhatikan gambar berikut ini :

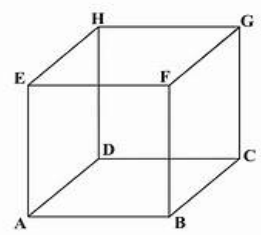

Gambar 1. Kubus sebelum diputar

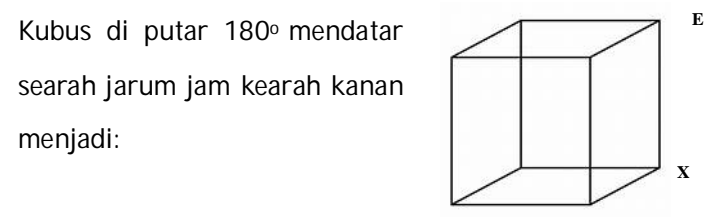

Gambar 2. Kubus setelah diputar

a. Nama titik sudut yang bertanda x pada gambar 2 adalah ? Berikan alasannya!

b. Bentuk segiempat $\mathrm{ABCD}$ pada kubus tersebut adalah?

c. Buatlah diagonal-diagonal ruang pada kubus ABCD EFGH! 
Beberapa jawaban dari siswa:
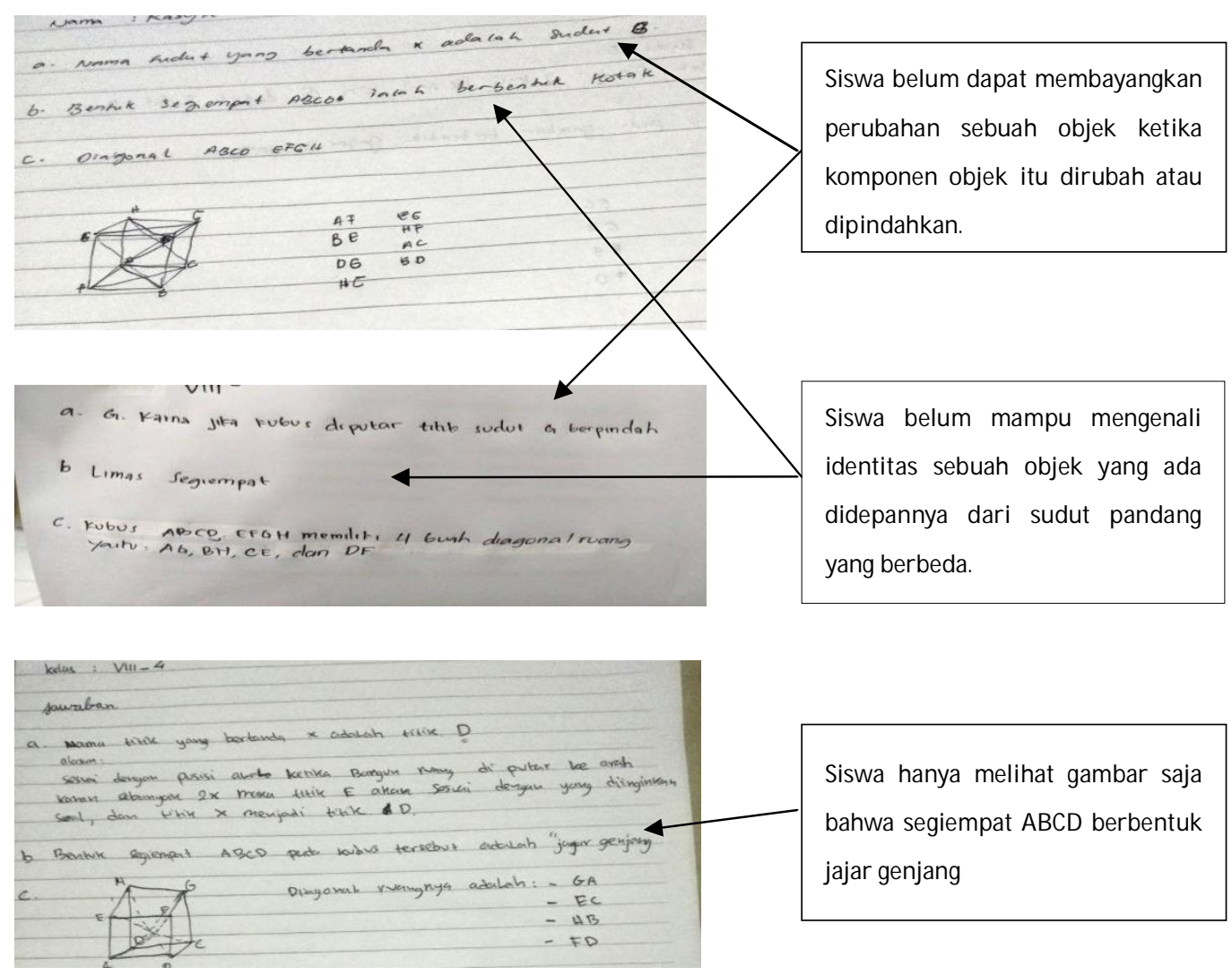

Siswa hanya melihat gambar saja bahwa segiempat ABCD berbentuk jajar genjang

Gambar 3. Beberapa hasil jawaban siswa pada studi pendahuluan

Dalam menjawab persoalan diatas, siswa harus memahami situasi dalam soal dengan tepat.Siswa diharapkan memiliki kemampuan dalam mengenali identitas sebuah objek yang ada dihadapnya dari sudut pandang yang berbeda, dan juga memiliki kemampuan untuk membayangkan perubahan sebuah objek ketika komponen objek itu dirubah atau dipindahkan. Akan tetapi, kenyataan yang diperoleh di lapangan beberapa siswa belum memiliki kepekaan dalam mengobservasi dan memiliki kemampuan untuk berpikir dalam gambar sehingga kemampuan agar bisa membayangkan bentuk-bentuk bangun ruang atau tiga dimensi masih dianggap rumit.

Pada solusi permasalahan diatas, secara garis besar hasil kerja siswa masih belum mampu memenuhi kemampuan spasial. Siswa masih mengalami kesulitan dalam membayangkan dan memvisualisasikan sebuah objek kerena selama ini pengembangan kemampuan spasial masih kurang diperhatikan dalam proses pembelajaran. Soal diatas merupakan bagian dari indiKator kemampuan spasial yaitu orientation dan mental rotation. Rendahnya kemampuan spasial tak lepas dari pengelolaan pembelajaran. Umumnya guru matematika saat mengajarkan materi 
bangun ruang lebih menekankan pada aspek ingatan saja. Misalnya pertanyaan tentang berapa banyaknya rusuk, sisi dan titik sudut dari berbagai jenis bangun ruang. Guru hanya memberikan contoh-contoh bangun ruang dengan menunjukan gambarnya saja tanpa memberikan bentuk nyata dari bangunan itu sendiri.

Salah satu alternatif model yang memungkinkan dapat mengembangkan kemampuan spasial adalah Pembelajaran Berbasis Masalah (PBM) yang dibantu dengan media pembelajaran alat peraga agar siswa bisa lebih memahami dengan baik materi bangun ruang yang diajarkan. Pada PBM dengan menyajikan masalah pada awal pembelajaran diduga siswa dapat mengemukakan pendapat, mencari informasi, bertanya, mengekspesikan ide-idenya secara bebas, mencari berbagai sumber yang tersembunyi, mencari berbagai alternative untuk mengatasi masalah. Diharapkan pembelajaran dengan metode PBM dapat menciptakan pendekatan pembelajaran kontruktif, siswa dapat membangun sendiri ilmu pengetahuannya yang diharapkan ingatan dan pemahaman terhadap konsep yang dipelajarinya tersebut dapat melekat ssecara permanen pada diri siswa. Tahapan Pembelajaran PBM yang digunakan dalam pembelajaran ini meliputi beberapa fase pembelajaran : 1) fase orientasi yakni mengorientasikan siswa pada masalah dunia nyata; 2) fase engagement, yakni siswa terlibat dalam aktivitas menyelesaikan masalah; 3) fase inquiry and investigation, yakni siswa melakukan penyelidikan dan investigasi dalam menyelesaikan masalah; dan 4) debriefing, yakni siswa melakukan tanya jawab dan diskusi terkait kegiatan penyelesaian masalah yang dilakukan (Lestari \& Yudhanegara, 2015).

Pada pembelajaran geometri bangun ruang, sangat tepat jika menggunakan metode PBM, karena untuk bisa memahami geometri sebaiknya siswa melakukan penyelidikan langsung terhadap sifat-sifat dan berbagai unsur dalam geometri khususnya pada bangun ruang. Dengan demikian, media dan alat peraga dapat digunakan oleh siswa berkemampuan rendah/ sedang untuk mengejar ketertinggalan dalam memahami konsep-konsep yang ada, dengan memperagakannya sesuai petunjuk yang ada. Menurut Nasution (2004) manfaat dari menggunakan alat peraga yaitu: (1) menambah kegiatan belajar siswa; (2) menghemat waktu belajar; (3) hasil belajar lebih permanen; (4) membantu siswa yang ketinggalan pelajaran; (5) membangkitkan minat, motivasi dan aktivitas pada siswa; dan (6) memberikan pemahaman yang lebih tepat dan jelas. Salah satu cara mengenalkan siswa kepada matematika dalam proses pembelajaran adalah dengan menggunakan bantuan alat peraga. Penggunaan alat peraga sangat berperan dalam penyampaian materi pelajaran bagi para pendidik yang mana dengan harapan alat peraga akan dapat memperjelas materi yang disampaikan.

Dengan demikian, media dan alat peraga berbahan pipet dapat digunakan oleh siswa berkemampuan rendah/ sedang untuk mengejar ketertinggalan dalam memahami konsep-konsep yang ada, dengan memperagakannya sesuai petunjuk yang ada. Di samping itu, hasil lebih permanen karena pengetahuan yang diperoleh melalui kegiatan belajar, melibatkan siswa secara langsung untuk mengkonstruksi konsep 
bangun ruang itu. Di samping itu, hasil lebih permanen karena pengetahuan yang diperoleh melalui kegiatan belajar, melibatkan siswa secara langsung untuk mengkonstruksi konsep bangun ruang itu.

Berdasarkan fakta-fakta yang terjadi dalam proses dan hasil belajar di atas maka guru dapat mendesain atau menciptakan suatu pembelajaran sehingga pendekatan pembelajaran yang diterapkan guru mampu diterima oleh kelompok siswa. Sehingga nantinya siswa dengan kemampuan tinggi, sedang maupun rendah bisa mendapatkan manfaat dari penerapan pendekatan pembelajaran yang dilakukan guru, khususnya dalam hal meningkatkan kemampuan spasial siswa terhadap matematika.

Berdasarkan uraian di atas, maka di rumuskan tujuan dari penelitian ini yaitu untuk mengetahui apakah peningkatan kemampuan spasial siswa yang diajarkan melalui model pembelajaran berbasis masalah berbantuan alat peraga berbahan pipet lebih tinggi dari kemampuan spasial siswa yang diajarkan melalui pembelajaran konvensional.

\section{Metode Penelitian}

Jenis penelitian ini merupakan quasi eksperimen (eksperimen semu) dengan desain penelitian pre-test-post-tes control group design. Populasi dalam penelitian ini adalah seluruh siswa kelas VIII SMP Swasta Al ulum Medan tahun ajaran 2019/2020 dengan mengambil sampel dua kelas (eksperimen dan kontrol) melalui teknik random sampling. Sampel yang terpilih yaitu kelas VIII-6 dan Kelas VIII-7. Dimana kelas VIII-6 sebagai kelas eksperimen yang menggunakan model pembelajaran berbasis Masalah berbantuan alat peraga dan kelas VIII-7 sebagai kelas kontrol yaitu kelas yang diberikan pembelajaran konvensional.

Instrumen yang digunakan dalam pengumpulan data adalah tes kemampuan spasial berbentuk uraian yang terdiri atas 5 butir soal yang sebelumnya telah dilakukan uji coba untuk menganalisis validasi, reliabilitas, tingkat kesukaran soal dan daya pembeda dengan bantuan microsoft excel. Data dianalisis dengan menggunakan uji ANAVA dua jalur. Setelah dilakukan uji normalitas dan uji homogenitas selanjutnya data dianalisis untuk mengetahui peningkatan kemampuan spasial siswa. Skor yang diperoleh dianalisis dari hasil tes sebelum dan setelah diberi perlakuan dengan cara membandingkan skor yang diperoleh dari hasil tes sebelum dan setelah dilakukan pembelajaran. Besarnya peningkatan sebelum dan sesudah pembelajaran dihitung dengan rumus gain ternormalisasi (normalized gain) sebagai berikut:

$$
\text { Gain ternormalisasi }(\mathrm{N}-\text { gain })=\frac{\text { skor posttest }- \text { skor pretest }}{\text { skor ideal }- \text { skor pretest }}
$$

\section{Hasil dan Pembahasan}


Tes kemampuan spasial diberikan kepada siswa sebagai pretes, yaitu tes sebelum pembelajaran berlangsung dan sebagai postes yaitu setelah pembelajaran berlangsung baik di kelas eksperimen maupun kelas kontrol. Pretes dan postes dilakukan untuk mengetahui peningkatan kemampuan spasial siswa pada kelas eksperimen dan kelas kontrol, dimana siswa pada kelas eksperimen memperoleh pembelajaran berbasis masalah berbantuan alat peraga sedangkan siswa pada kelas kontrol memperoleh pembelajarn konvensional. Kegiatan pembelajaran berbasis masalah diawali dengan pemberian masalah pada siswa, kemudian siswa melakukan eksperimen secara berkelompok dengan menggunakan alat peraga berbahan pipet untuk mendapatkan jawaban masalah yang diajukan. Kegiatan seperti ini memungkinkan siswa menemukan jawaban masalahnya bukan karena diberitahu oleh guru melainkan siswa sendirilah yang menemukan jawabannya sendiri. Dalam proses pembelajaran guru hanya sebagai fasilitator bagi siswa dalam rekontruksi ide dan konsep matematika. Serangkaian kegiatan pembelajaran dengan model pembelajaran berbasis masalah berbantuan alat peraga berbahan pipet mengakibatkan siswa berperan aktif selama pembelajaran berlangsung karena melakukan berbagai kegiatan yang menuntut siswa lebih aktif bekerja dan berpikir. Berbeda halnya dengan pembelajaran konvensional yang dalam pembelajarannya guru harus dituntut aktif dan murid juga harus mengikuti seluruh arahan dari guru sehingga jika guru tersebut tidak aktif maka pembelajaran tidak sampai dengan sempurna kepada siswa tersebut.

Adapun peningkatan rata-rata hasil tes kemampuan spasial matematis siswa antara pretest dan postes untuk kelas ekserimen dan kelas kontrol dapat dilihat pada gambar 1 :

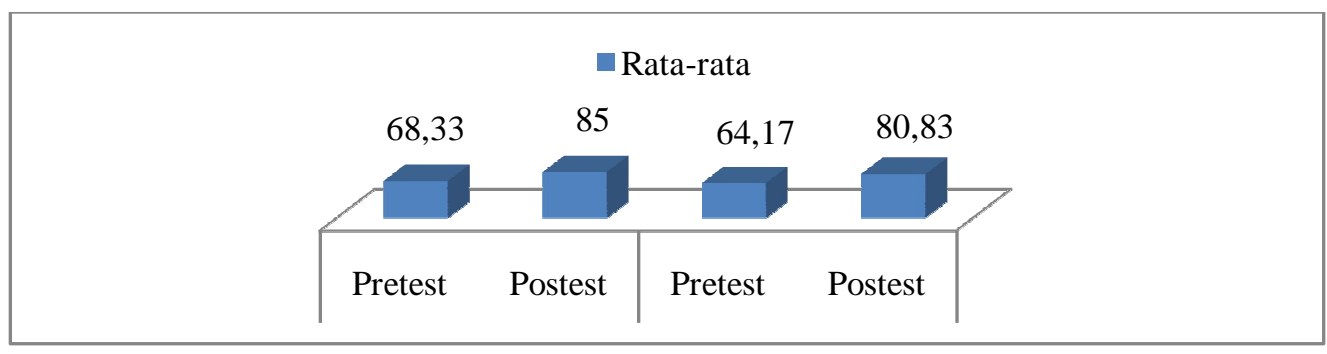

Gambar 4. Hasil Rata-rata Pretest dan Postest Kemampuan Spasial Siswa Pada Kelas eksperimen dan Kelas Kontrol

Pada gambar 4 dapat dilihat bahwa rata-rata nilai pada kelas eksperimen lebih tinggi daripada rata-rata nilai pada kelas kontrol. Untuk hasil postest dan pretest pada masing-masing kelas terdapat perbedaan dimana pada kelas eksperimen hasil postest lebih tinggi daripada rata-rata pretest, yaitu $85,00>68,33$, hal ini menunju- 
kan bahwa terdapat peningkatan rata-rata hasil tes kemampuan spasial siswa pada kelas eksperimen sebesar 16,67. Demikian juga pada kelas kontrol hasil postest lebih tinggi daripada rata-rata hasil pretest yaitu 80,83>64,17 hal ini menunjukan bahwa terdapat peningkatan rata-rata hasil tes kemampuan spasial siswa pada kelas kontrol sebesar 16,66.

Dari hasil pretest dan postest dihitung peningkatan (N-Gain) kedua kelas untuk mengetahui besar peningkatan kemampuan spasial matematis pada siswa kelas eksperimen dan kelas kontrol.

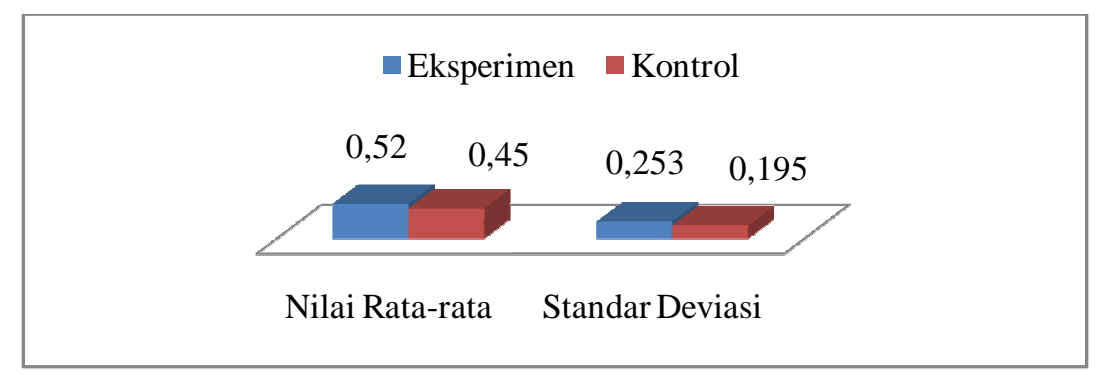

Gambar 5. Diagram Data Indeks N-Gain Kemampuan Spasial Siswa

Pada Gambar 5 terlihat bahwa rata-rata indeks N-gain kemampuan spasial matematis siswa di kelas eksperimen $(0,52)$ lebih tinggi dibandingkan siswa di kelas kontrol $(0,45)$. Demikian dengan standar deviasi indeks n-gain kemampuan spasial matematis siswa di kelas eksperimen $(0,253)$ lebih tinggi dibandingkan siswa kelas kontrol $(0,195)$. Hal ini menunjukan bahwa peningkatan kemampuan spasial kelas eksperimen lebih tinggi daripada peningkatan kemampuan spasial siswa kelas kontrol.

Hasil perhitungan uji hipotesis dianalisis dengan bantuan program SPSS 24 dapat dilihat pada tabel 1:

Tabel 1. Hasil Perhitungan Analisis Uji Hipotesis dengan Anava Dua Jalur

\begin{tabular}{|c|c|c|c|c|c|c|}
\hline \multicolumn{7}{|c|}{ ANOVAa } \\
\hline Model & & Sum of Squares & $\mathrm{Df}$ & Mean Square & $\mathrm{F}$ & Sig. \\
\hline \multirow[t]{3}{*}{1} & Regression & 133,753 & 1 & 133,753 & 5,928 &, $030^{b}$ \\
\hline & Residual & 293,330 & 13 & 22,564 & & \\
\hline & Total & 427,083 & 14 & & & \\
\hline \multicolumn{7}{|c|}{ a. Dependent Variable: control } \\
\hline \multicolumn{7}{|c|}{ b. Predictors: (Constant), eksperimen } \\
\hline \multicolumn{7}{|c|}{ Coefficients $^{a}$} \\
\hline \multirow{2}{*}{\multicolumn{2}{|c|}{ Model }} & \multirow{2}{*}{\multicolumn{2}{|c|}{ Unstandardized Coefficients }} & Standardized & & \\
\hline & & & & Coefficients & $\mathrm{T}$ & Sig. \\
\hline
\end{tabular}




\begin{tabular}{|c|c|c|c|c|c|c|}
\hline & & B & Std. Error & Beta & & \\
\hline \multirow[t]{2}{*}{1} & (Constant) & 46,991 & 13,954 & & 3,368 & 005 \\
\hline & Kelas & 398 & 164 & ,560 & 2,435 & ,030 \\
\hline
\end{tabular}

a. Dependent Variable: control

Berdasarkan tabel 1 hasil analisis anava dua jalur untuk model pembelajaran diperoleh nilai sig sebesar 0,030 . Karena nilai signifikan lebih kecil dari $\alpha=0,05$ $(0,030<0,05)$ maka dapat disimpulkan bahwa $\mathrm{H}_{0}$ ditolak dan $\mathrm{H}_{\mathrm{a}}$ diterima yang berarti terdapat perbedaan peningkatan kemampuan spasial matematis siswa yang diajarkan dengan model pembelajaran berbasis masalah berbantuan alat peraga dan pembelajaran konvensional.

Berdasarkan hasil penelitian diketahui bahwa peningkatan kemampuan spasial siswa yang diberi model pembelajaran berbasis masalah berbantuan alat peraga lebih tinggi dibandingkan dengan pembelajaran konvensional. Hal ini dikarenakan pembelajaran model PBM berbantuan alat peraga memiliki keunggulan serta penggunaan yang tepat digunakan dalam proses pembelajaran. Hal ini sejalan dengan penelitian Argaw, dkk. (2017) yang berjudul "The Effect of problem based learning (PBL) instruction on students' motivation and problem solving skill of physics" mengatakan bahwa kemampuan pemecahan masalah yang diajarkan dengan pembelajaran berbasis masalah mengalami peningkatan dengan nilai rata-rata sebesar 50,24. Hal ini dikarenakan pembelajaran berbasis masalah melatih siswa untuk mengembangkan keterampilan sosial yang bermanfaat untuk diskusi kelompok.

Dalam proses pembelajaran melalui model pembelajaran berbasis masalah berbantuan alat peraga, memberikan kesempatan secara langsung kepada siswa untuk memanipulasi benda-benda konkret sesuai dengan permasalahan yang diberikan sehingga siswa menjadi lebih mudah dalam memahami apa yang sedang dipelajari. Kegiatan pembelajaran berbasis masalah yang diawali dengan pemberian masalah pada siswa, selanjutnya siswa melakukan eksperimen secara mandiri untuk mendapatkan jawaban darimasalah yang diajukan.

\section{Kesimpulan}

Berdasarkan hasil analisis data dan pembahasan maka diperoleh kesimpulan yakni peningkatan kemampuan spasial matematis siswa yang diajarkan dengan model pembelajaran berbasis masalah berbantuan alat peraga lebih tinggi dari siswa yang diajarkan dengan model pembelajaran konvensional.

\section{Ucapan Terimakasih}

Penulis mengucapkan terima kasih kepada Kepala SMP Swasta Al Ulum Medan, 
Bapak Hery Herwanto, S.Pd., M.Pd. yang telah memberi kesempatan untuk melakukan penelitian di sekolah tersebut.

\section{Daftar Pustaka}

Argaw, A.S, Haile, B.B. Ayalew, B.T \& Kuma, S.G. 2017. The effect of problem based learning (PBL) instructionon students' motivation and problem solving skills of physics. EURASIA Journal of Mathematics Science and Tecnology Education.

Lestari, K.E. \& Yudhanegara, M.R. (2015). Penelitian Pendidikan Matematika. Bandung: PT. Refika Aditama.

Maier, P. H. 1996. Spatial Geometry and Spatial Ability How toMake Solid Geometry Solid?.Tersedia pada http:/ / www.find.uni-osnabrucck.de/ ebooks/ gdm/ peperspdf1996/ Maier.pdf. (diakses tanggal 5 april 2019)

Mulyadi, Riyadi, \& Subanti, S. (2015). Analisis Kesalahan Dalam Menyelesaikan Soal Cerita Pada Materi Luas Permukaan Bangun Ruang Berdasarkan Newman'S Error Analysis (Nea) Ditinjau Dari Kemampuan Spasial. Jurnal Elektronik Pembeljaran Matematika, 3(4), 370-382.

Nasution, S. (2004). Dikdaktik Asas-asas Mengajar.Jakarta. Bumi Aksara.

Siswanto, R. D. (2016). Asosiasi Antara Kemampuan Geometri Spasial Dengan Kemampuan Berpikir Kreatif Matematis Siswa. KALAMATIKA Jurnal Pendidikan Matematika, 1(2), 141. 